\title{
The Florida Automated Weather Network (FAWN): Ten Years of Providing Weather Information to Florida Growers 1
}

William Lusher, John Jackson, and Kelly Morgan ${ }^{2}$

\section{History}

For almost 50 years the National Weather Service (NWS) collected data in rural locations and issued agricultural forecasts and advisories to alert Florida growers to potential freeze conditions. On April 1, 1996 the NWS discontinued this service in an effort to reduce expenses. On the night of January 18-19, 1997, temperatures were expected to drop into the mid to upper 30s. However, this forecast was based on data collected at city and airport sites which are typically warmer than rural areas. That night, temperatures in rural locations ended up much lower than forecasted and significant damage (an estimated $\$ 300$ million) resulted primarily to winter vegetables (Lucier and Love, 1997). Due to the lack of rural weather information, growers were not aware of the potential for damaging temperatures. In response to this event, an Agricultural Weather Task Force was formed to find a solution to this problem - the lack of agricultural weather information. The task force was composed of members of the Florida Farm Bureau, the Florida Fruit and Vegetable Association, Florida Citrus Mutual, the Florida Nurseryman
Association, Growers, and Landscape Association, the Florida Department of Agriculture and Consumer Services, Senator Bob Graham's office, and the University of Florida Institute of Food and Agricultural Sciences (UF/IFAS). The recommendation of the task force was the installation of a network of automated weather stations located in rural locations that would provide representative data and weather-related information to growers in Florida.

The Florida Automated Weather Network (FAWN) was initiated in 1997 with a legislative appropriation to UF/IFAS. Eleven sites were established and integrated into an existing county Cooperative Extension Service network of 5 sites in Lake and Orange counties in 1998. Figure 1 shows the locations of the 16 original sites. Over the next three years 5 sites were added bringing the total to 21 . In 200212 more sites were added, primarily in north and west Florida, bringing the total number of locations to 33. In 2004 sites were added in Arcadia and Frostproof, and in 2007, a station was installed near Clewiston. Over time several stations were

1. This document is SL 298, one of a series of the Soil and Water Science Department, Florida Cooperative Extension Service, Institute of Food and Agricultural Sciences, University of Florida. Original publication date July 2009. Revised August 2009. Visit the EDIS Web Site at http://edis.ifas.ufl.edu.

2. William Lusher, director, FAWN Project, IFAS Office of Information Technology; John Jackson, extension agent and FAWN coordinator, Lake County Extension; Kelly Morgan, assistant professor, Department of Soil and Water Science, Southwest Florida Research and Education Center (REC)--Immokalee; Florida Cooperative Extension Service, Institute of Food and Agricultural Sciences, University of Florida, Gainesville, FL 32611.

The Institute of Food and Agricultural Sciences (IFAS) is an Equal Opportunity Institution authorized to provide research, educational information and other services only to individuals and institutions that function with non-discrimination with respect to race, creed, color, religion, age, disability, sex, sexual orientation, marital status, national origin, political opinions or affiliations. U.S. Department of Agriculture, Cooperative Extension Service, University of Florida, IFAS, Florida A. \& M. University Cooperative Extension Program, and Boards of County Commissioners Cooperating. Millie Ferrer, Interim Dean. 
relocated, and others removed, for a total of 35 sites. FAWN's database, originally designed by UF faculty and graduate students has been upgraded and is now housed in the University of Florida Computer Center with 24 hour support.

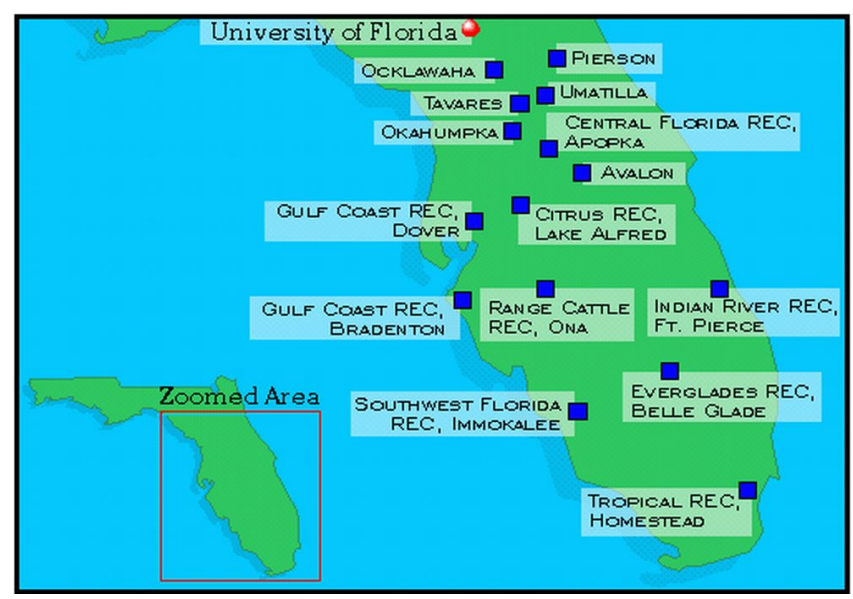

Figure 1. Locations of original 16 FAWN sites.

\section{Present}

Figure 2 shows the current locations of FAWN's 35 sites, located from Homestead to Jay, near Pensacola. Future plans are to add sites to areas that lack coverage, for a maximum of 40 sites. Most sites are located at UF/IFAS research centers, USDA facilities, Florida Division of Forestry sites, state/county parks, and county Extension offices. FAWN continues as a program of UF/IFAS, residing in the Information Technology unit, and working closely with the UF/IFAS Deans for Extension and Research. FAWN maintains an Advisory Committee comprised of individuals from industry organizations, water management districts, and other state and federal agencies, which provides oversight for the program. UF/IFAS, South Florida Water Management District, Southwest Florida Water Management District, St. John's River Water Management District and the Florida Department of Agriculture and Consumer Services provide most of the annual operating budget for FAWN. Other "Sponsors"- private companies, associations, and individuals - contribute annually to help offset some of FAWN's operating expenses. A business plan is also in place that outlines long term goals related to the development of new production weather-related tools (e.g. cold weather protection and irrigation scheduling), location of additional sites, data delivery, tool enhancement, and educational efforts.

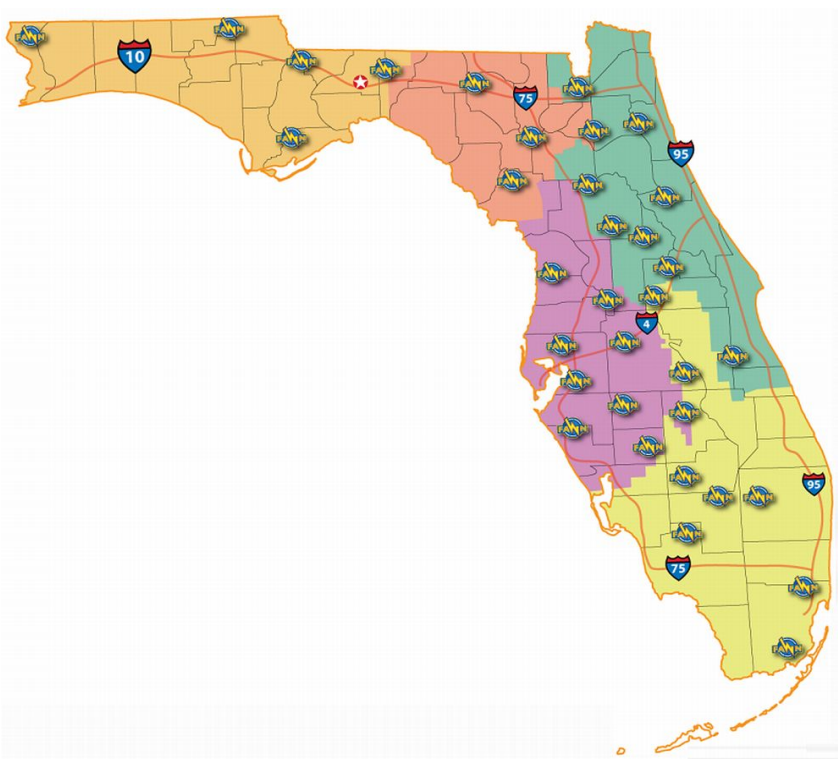

Figure 2. . Current FAWN observing site locations, with water management districts indicated by the shaded regions.

\section{Data Collection and Delivery}

Each FAWN tower is equipped with sensors that measure a number of parameters, including temperature $(-10 \mathrm{~cm}, 60 \mathrm{~cm}, 2 \mathrm{~m}$, and $10 \mathrm{~m})$, barometric pressure, solar radiation, wind speed and direction, and rainfall amount. Several parameters are calculated as well, including dew point temperature, and evapotranspiration. Figure 3 shows the configuration of a typical FAWN tower. Detailed information on the sensors used and tower configuration can be obtained from the FAWN Web site at http://fawn.ifas.ufl.edu/tour/tech_info.php.

Data are collected at each FAWN site every 15 minutes and stored by a data logger. UF data servers retrieve data from each site in one of two ways, depending on its location. Towers located on UF property are connected to the local computer network via a two-way radio system. The local server connects to the database via the Intranet. Towers located on non-UF property are connected via cellular phone directly to the database server. Approximately two-thirds of FAWN towers are located on UF property, and are therefore, connected to the local Intranet. The remaining sites utilize the cellular network. Once all data are collected, they are 
compared to a known standard range of acceptable values, and then processed into the master database, and the online database (for access via the FAWN Website). Once processed into the online database, data are displayed, used to create summaries, and incorporated into the FAWN management tools.

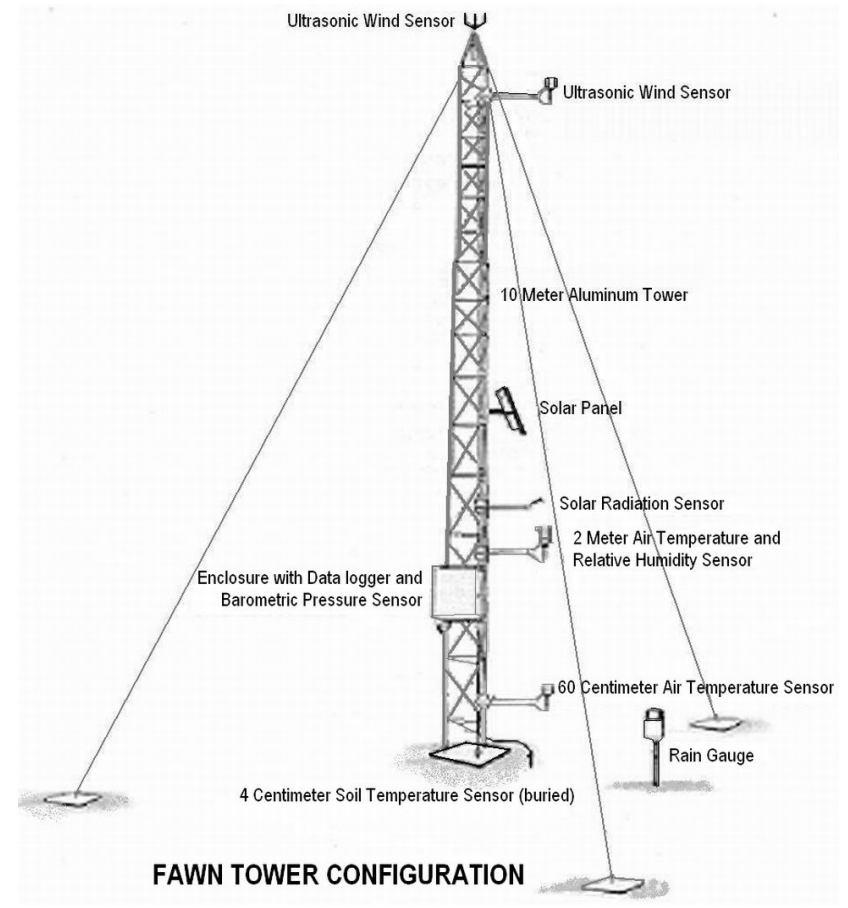

Figure 3. Configuration of a typical FAWN tower.

\section{Data Access}

The overarching goal of FAWN is to "provide timely and accurate weather data to a wide variety of users," and to be considered the most reliable and useful source of real time weather data in Florida. Additionally, by providing effective management tools to assist decision makers, FAWN can also have a substantial financial impact on numerous segments of Florida and be a valuable asset to resource managers and those involved with protecting life and property. Visitors to the FAWN Web site in 1998 had a limited number of options (Figure 4 shows what a visitor to the site would have seen). Users could view current data from all or selected sites in table format; data from a selected site on a line graph; and daily, weekly, and monthly summaries from a selected site. Additionally, there was some information about data collection, a map of locations, and links to external resources.
During the 10 years since its inception, the FAWN system has undergone a number of improvements and enhancements. Expansion of the network, development of new management tools, and data quality have been at the forefront of these improvements. The FAWN Web site has also seen a number of revisions. Figure 5 shows several pages from the FAWN Web site launched in 2009. With this revision came an improved user-interface, enhanced data access, and more efficient management tools. The Homepage shows a map of the state of Florida with 2 meter air temperature displayed at each FAWN location. Specific ranges of values are assigned a color/shade to indicate warmer or cooler conditions. Among other features, there are links to all pages within the site, as well as a News Box, where current information about FAWN can be posted and easily accessed. The FAWN Management Tools page has 10 weather-related management tools (several are shown in Figure 5) to aid users with cold protection, irrigation scheduling, and disease control. Planned enhancements to these tools include integrating real-time data from nearby FAWN sites into the tool for improved decision-making. For example, the Urban Irrigation Scheduler suggests an irrigation schedule based on geographical region--using climatological rainfall--and sprinkler-type. Real-time rainfall and evapotranspiration data from the FAWN site nearest the user's location will enhance this tool for a more informed decision regarding irrigation. The Report Generator allows the user to retrieve archived data from any (or all) of the FAWN sites. Users can view results in a table on the screen, or download the results in .CSV format for display in a spreadsheet application. The FAWN Web site also includes a monthly FAWN FOCUS, an article that contains information on various topics related to weather, climate, agriculture, and using the Web site.

In addition to data access via the Internet, users can listen to current observations at any FAWN site via the FAWN Interactive Voice Response System. This system allows users to call a toll-free phone number, enter a 3-digit station ID number, and listen to the latest values of all observed parameters. This can be particularly useful when current data are still needed, but access to the FAWN Web site is not practical. 


\section{Management tools}

From the inception of FAWN it was evident that the project had to have more than weather data. The original concept was to assist growers with managing their crops during cold weather. FAWN has made a concerted effort to develop Management Tools to aid users with decision making. The first tools were naturally in the area of cold protection. A detailed explanation of these tools can be found elsewhere in this publication. FAWN will continue to seek new ways to assist users with the decision making process.

\section{Management Tools are a key component to the success of FAWN.}

Part of FAWN's mission is informing the public about its services and products. This is accomplished in several ways. FAWN attends trade shows and conferences to conduct presentations and exhibits about various components of the program; use of the tools, and data access, for example. FAWN also makes presentations to user groups around the state, such as fern growers and homeowners. FAWN is currently involved in a student 4-H outreach effort in which students will learn in a hands-on environment about weather and climate, conducting routine weather observations using different platforms (e.g., manual and automated), and use of weather and climate data.

\section{Impact}

Accountability is extremely important to FAWN. Financial support for the program comes from a number of public agencies and private sources, and each need to know their support is making a positive impact through FAWN.

According to the members of the Agricultural Weather Task Force, FAWN has had a multi-million dollar impact on agriculture through more informed production, harvesting, and marketing decisions. While there has been no major attempt to document the overall impact, feedback from non-agricultural users indicates substantial use and value. For example, The NWS uses FAWN data when

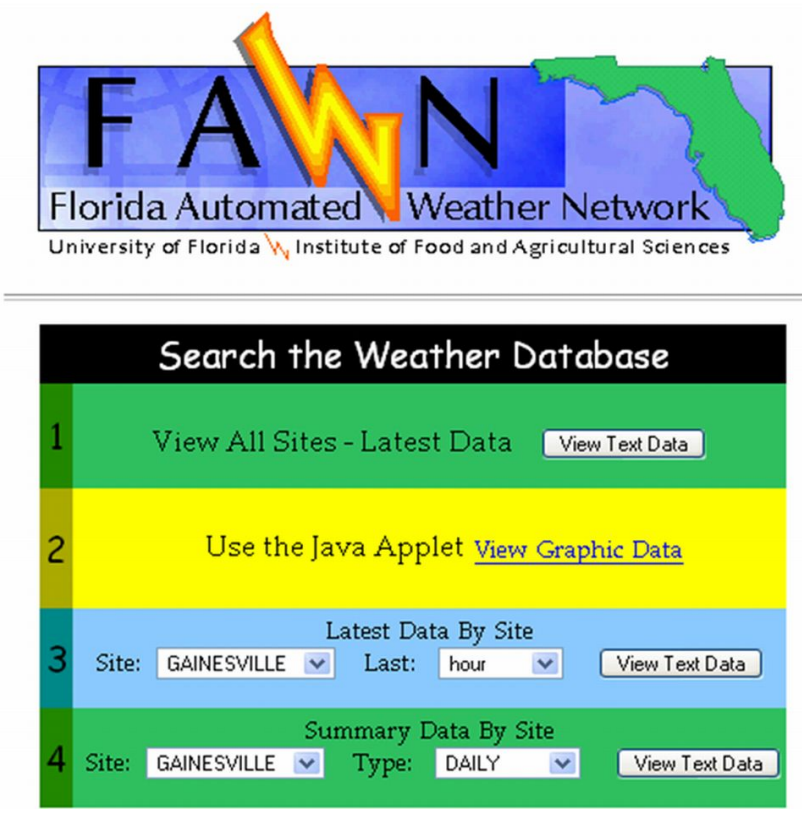

Figure 4. First FAWN homepage in 1998.

evaluating fire risks and developing high-resolution surface maps; the Florida Division of Emergency Management uses the data when tracking the southward progression of cold air, to monitor wind speeds during hurricanes, and in making decisions regarding potential risks from weather events; the Florida Division of Forestry relies on the information in issuing burning authorizations, fighting forest fires and in monitoring smoke plumes; University of Florida researchers use the data for many projects ; and various media outlets have incorporated the data into numerous articles and presentations (WESH in Orlando, FL uses FAWN data for early morning reports, for example).

Statistics have been collected regarding the use of the FAWN Web site. Table 1 below best shows the level of use for the past ten (10) years. There has been a steady increase in visitors and peak use continues to occur during freeze events as shown below.

It has been determined that users of FAWN data and tools for cold protection can potentially save substantial amounts of water and numerous dollars. Using information from the Florida Agricultural Statistics Service, Florida Citrus Mutual, the Florida Strawberry Association, the Florida Fern Growers Association, the Florida Nurserymen, Growers and Landscape Association, and the Florida Fruit and Vegetable Association, estimates of potential savings 
have been calculated (Table 2). FAWN Cold

Protection tools provide growers with a guide for when to start and stop irrigation used for cold protection. Use of FAWN Cold Protection tools can save an estimated 2 hours of irrigation per cold event, which can bring about substantial savings over a winter season. For example, during a relatively warm winter, 1 to 3 nights may require cold protection for a total savings of 2 to 6 "irrigation-hours." A cold winter, however, may produce 4 to 10 nights requiring cold protection for a savings of 8 to 20 hours. Therefore, the average number of gallons of water and dollars saved during relatively warm and cold winters can be estimated (Table 2). Depending on the number of nights that need protection, 7 - 25 billion gallons of water and $\$ 3-13$ million can potentially be saved by using FAWN Cold Protection tools.

\section{Recognition of FAWN's impact}

FAWN was presented the Davis Productivity Award in 1998 as the top state project regarding teamwork, productivity, and performance. And in 2004 the FAWN team received the USDA Award for Superior Service, one of three awarded from the thousands of projects across the country. FAWN has been extremely successful due the hard work of many; it has truly been a team effort. Growers, irrigators, pest managers, cold protectors, fire fighters, researchers, weather nuts, and many others all enjoy the benefits of FAWN due to the vision and hard work of the founders, staff, administrators, advisory committee, financial partners and idea contributors. It has been a most productive first ten years for FAWN and has laid the groundwork for continued improvement in the delivery of quality weather data and management tools well into the future.

\section{Conclusion}

FAWN is one product of the freezes that occurred during the 1980's. Timing is everything and FAWN certainly is a good example. There was a need for automated weather information in order to more efficiently deal with cold weather. Technology had advanced to provide accurate equipment at a reasonable cost. The National Weather Service

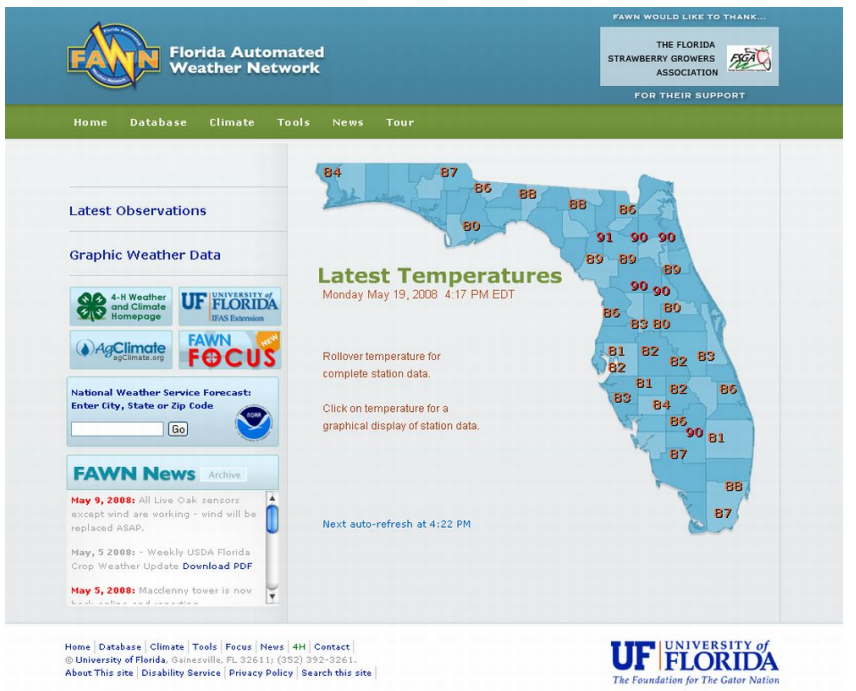

Fig. 5a. The current FAWN Website (2009). The Homepage, Management Tools page, and Report Generator page are shown.

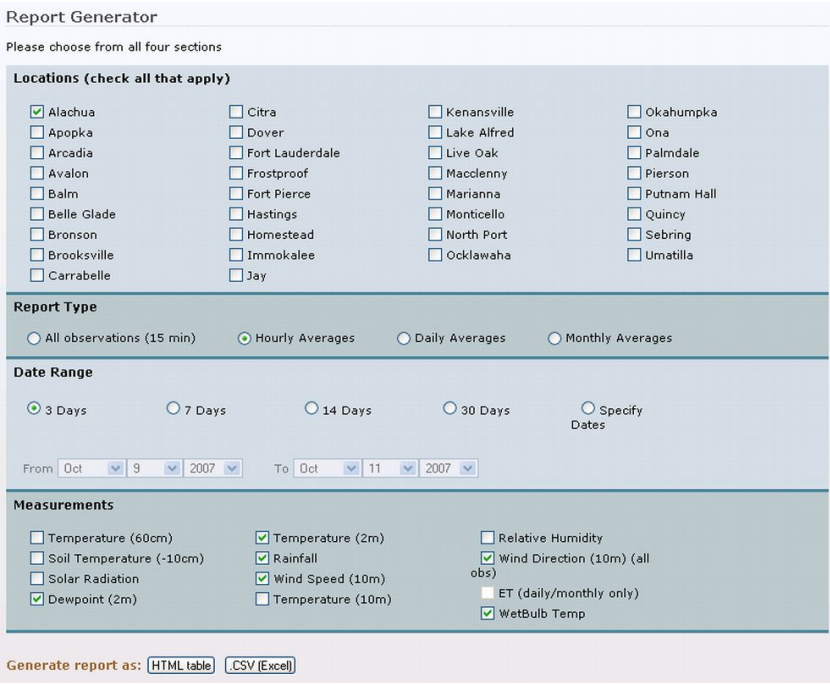

eliminated agricultural products. A collection of competent and motivated individuals saw the need and responded. Thus FAWN evolved into a state-wide network of automated weather sites that have provided weather data for many users for the benefit of the citizens of Florida. Creative individuals will continue to develop new and beneficial products using the FAWN weather data. Some of these products will be a Management Tool while others will be housed with the developer. No matter the location, FAWN will continue to be a major contributor of accurate and timely weather information for a wide variety of users. Due to the hard work of many, FAWN was established and continues to operate in a cost effective mode. Using University of Florida faculty and staff allowed for the 
establishment of FAWN with minimum cost.

Excellent support from public and private sector

funding provides data and tools at no cost to the user.

FAWN has been, and will continue to be successful

because it provides useful information which justifies

broad-based financial support.

\section{Acknowledgements}

A special note needs to be added to the FAWN story. Without the leadership and encouragement of Dr. Jim App, former Assistant Dean for Extension, FAWN would never have progressed past the Agricultural Weather Task Force. Dr. App convinced Mr. Jackson to develop the proposal, secured a one-year transfer for Mr. Ayers to spend full time designing and installing towers, interacted with UF/IFAS administration to accept the challenge of sponsoring the project, convinced research station directors to cooperate by providing labor and site locations, secured support from research by convincing the Assistant Dean for Research to serve on the management team, obtained the services of UF/IFAS External and Media Relations to publicize the effort, and much more. Professor Howard Beck, UF/IFAS Information Technology unit and his graduate students designed and operated the original data base and Web site. Visionary leadership provided by Dr. Fedro Zazueta, former UF/IFAS Director of Information Technology provided existing faculty and staff for operation of FAWN.

Without financial support from public and private sources FAWN could not exist. The list of sponsors can be found on the Web site. FAWN and the citizens of Florida owe a tremendous debt of gratitude and appreciation to the following agencies and their staff that have worked hard to keep FAWN financially alive and well for ten years.

Southwest Florida Water Management District

South Florida Water Management District

Florida Department of Agriculture - Office of Agricultural Water Policy

St. Johns River Water Management District 
Table 1. History of Average number of pages viewed per month and peak level of use.

\begin{tabular}{||l|r|r|r||}
\hline \hline Year & $\begin{array}{c}\text { Average Number of Pages } \\
\text { Viewed Monthly }\end{array}$ & $\begin{array}{c}\text { Number of Pages } \\
\text { Viewed for Highest } \\
\text { Month }\end{array}$ & $\begin{array}{c}\text { Month with } \\
\text { Maximum Pages } \\
\text { Viewed }\end{array}$ \\
\hline 2004 & 170,000 & 260,000 & Jan \\
\hline 2007 & 212,000 & 431,000 & Feb \\
\hline 2008 & 266,000 & 462,000 & Jan \\
\hline \hline
\end{tabular}

Table 2. Water savings estimates and associated savings using FAWN Cold Protection Toolkit.

\begin{tabular}{||r|r|l|l|r||}
\hline \hline $\begin{array}{l}\text { Hours } \\
\text { Saved }\end{array}$ & Winter Type & $\begin{array}{l}\text { Average \# of } \\
\text { Nights } \\
\text { Protected }\end{array}$ & $\begin{array}{l}\text { Total Volume Saved } \\
\text { (gallons) }\end{array}$ & Total Cost Saved (USD) \\
\hline 2 & Warm & 2 & $7,215,216,000$ & $\mathbf{3 , 7 8 0 , 1 6 8}$ \\
\hline 2 & Cold & 7 & $25,242,600,000$ & $\mathbf{1 3 , 2 3 0 , 5 8 8}$ \\
\hline \hline
\end{tabular}

